\title{
The Network-Platform Construction and Website-Based College English Teaching Practice
}

\author{
Wenlian, Zhan ${ }^{1, \mathrm{a}}$, Zhulin, Shen ${ }^{1, \mathrm{a}}$ \\ ${ }^{1}$ School of Foreign Languages,Hunan International Economics University \\ Changsha, China \\ ae-mail: 513869962@qq.com
}

\begin{abstract}
With the rapid development of modern educational technology and fast growth of the web-based instruction, how to bring into full play the advantages of web-technology in College English web-teaching has become a current research task. Accordingly, this paper mainly demonstrates the importance of web-platform construction and application of its systematic functions as well.
\end{abstract}

Keywords-network-platform;web-course;College

English teaching; network-assisted teaching.

\section{INTRODUCTION}

With the rapid development of computer and network technology, online education provides a new concept for college English teaching reform in China, with the support of the rich teaching resources and the necessary software and hardware environment. Compared to traditional teaching mode, online education has several distinct advantages. It urges people to learn modern teaching technology and change the traditional concept of roles of the teacher and the students, resulting the dominant position of students, which is conducive to the cultivation of students' abilities and qualities.

Online education is a particularly close related to public English teaching reform. To modern information technology, especially network technology to support the new teaching model, creating a virtual teaching and learning environment, provide a great deal of information resources, teaching is no longer subject to the restrictions of time and space, personalized learning for students, independent Learning to create the conditions.

But with the network environment support is not equal to the foreign language teachers will be able to successfully carry out online teaching. One of the reasons is that online teaching is not just one-way to publish online information of foreign language teaching, conveying foreign language resources, more importantly, the students and teachers, a two-way interaction and communication between the students and the students online. To achieve this purpose, the need to develop a network of dedicated tools and design interactive program. However, the majority of foreign language teachers know little about computer and network technology, it is difficult to achieve the development of network tools. In this case, there is an urgent need to build a network teaching platform, shielding the complexity of the program design, implementation of online teaching tools provide concise support for foreign language teachers. Network platform has played an extremely important role in the College English Teaching Online. So in the network environment with the case, the key to online teaching is that the construction of network teaching platform and to serve as a platform, which is a prerequisite to ensure that foreign language teachers to open network courses.

Usually network teaching platform is built on a common Internet / intranet basis by specialized software to provide comprehensive services based on two-way multimedia communication network teaching system. The main components are: the network teaching system, courseware development and teaching resources management system. Each system has its particular features, foreign language teachers based on the task of teaching and teaching characteristics help of some of the tools provided by the network platform, using the effective functioning of the system, to provide distance learning. Teaching management system to protect this kind of teaching is more efficient and standardized.

\section{NETWORK COURSEWARE ON-DEMAND AND LIVE ONLINE TEACHING}

Network courseware on demand and online teaching live teaching system to achieve through the network platform. Network teaching system is a set of network teaching system software, and support of the teaching management system, reasonable and effective use of the resources of foreign language teaching.

\section{A. Implementation of network courseware on demand}

In order to make teaching more vivid, more intuitive, and foreign language teachers often make or buy some teaching demonstration courseware. Function is one of the network platform to play audio and video courseware and synchronous playback of teachers making the speech power point or flash or other relevant information, such as: text background synchronization exercises, self-testing. Some data can also be stored on the server. Students in the client terminal can be synchronized on-demand information school teachers can also pause to a certain period of lectures live access to the information provided by teachers.

The network teaching focuses on the development of high-quality network courseware (web-based courseware). The ideal network courseware is not only rich learning content, strong openness and interactivity, should also design comprehensive teaching management functions to monitor student learning. However, the need to have a network of professional technology and production of courseware development tools to produce high-quality courseware, 
foreign language teachers in general do not have these conditions. The role of one of the network teaching platform is to provide a simple and practical network courseware development tools for foreign language teachers, reduce the courseware development technical difficulty, and simplify the process of teachers in the development of network courseware. For example: You can import multimedia material processing visually adjusted quickly generate network courseware available online for students on demand.

With the increase in the network courseware types of English teaching, courseware CTR will continue to increase. Students can be anywhere in the campus (as long as there is a microcomputer), according to their own timetable, ondemand want to learn the content, which gives students independent study to create excellent conditions.

\section{B. To achieve network teaching live}

Network teaching live in live classroom. The live indoor set the different camera orientation, the intake of teachers and students in classroom activities scene from different angles. Network platform has a desk, and technical personnel responsible for Lens round and switch. Unlike courseware on demand, live content is not play the video information stored in advance, but sent directly to the student end of the play. In order to improve the quality of live, instructor must discuss with the technical staff and co-designed the lecture script (teaching plans), taped in order to achieve the best results. Conditional schools can create a few more live classroom, the audio and video streams of the same or different levels of foreign language courses spread to other classrooms via live server. Students can watch a class taught live in different locations, you can also free to switch to a different scene.

School teachers, non-real-time on-demand can also be achieved. The technical staff of the material collected the necessary editing processing using a compatible format stored in the server for students on demand.

The significant network teaching is characterized by: the constraints of time between teachers and students can not establish an effective online environment of open, interactive communication. Teachers and students using online teaching tools such as: Email, BBS, Chatroom and other text-based communication tools, synchronous or asynchronous learning and counseling. Network platform can be achieved during a live interactive capabilities of teachers and students in the classroom. Graphics, voice, video and other multimedia network classroom, can also be provided through audio and video conferencing systems support, image, intuitive performance of a mutual exchange of teachers and students in remote scenarios. Teachers in a live classroom of students live room and live viewing room to ask questions or answer questions from students, and vice versa. This makes the the network English classroom teacher-student interaction in the true sense of the place. This real-time online interaction helps teachers to keep abreast of student learning, help teachers teaching humane. In particular, it is worth mentioning: a live room can be connected with several viewing rooms, instructors can switch the screen to see the students of the viewing room, convenient for teachers to control the quality of student learning. At the same time due to the selection of outstanding teachers to engage in live, limited teacher resources are optimized configuration, to improve the teaching effect.

\section{COMPREHENSIVE EVALUATION}

Teaching evaluation is an important part of the teaching process. Teaching evaluation by artificial completed, both time-consuming and inaccurate. Network platform evaluation system will not only be able to test, analyze and record students' final examination, but also to conduct a comprehensive assessment of the students usually complete learning tasks online, to provide reliable data for the the transitional assessment and summative assessment.

Comprehensive network evaluation software system has the function of the Online Test Paper Generation and analysis of test results. Teachers based on the curriculum requirements tissue papers generated changes in the examination of the kinds of questions, the proportion of allocation subjective questions and objective questions, highlighting the focus and difficulty of the test. In addition, the system can be used for statistical analysis of the result of the test, to analyze the difficulty of the questions, the reliability and discrimination, to help teachers understand the quality of the papers, diagnose student learning while carefully study exam in information on teaching washback (backwash) role.

Recommended by the Ministry of Education sets educational software system design students self-test function. Students online independent learning

Textbooks should be set by the respective units through the system and the level of the test, the system automatically records the student's test results. In addition, the network test database there are tens of thousands Road 1-4 level questions, students enter the testing requirements, through the browser in any learning terminal evaluation system can be automatically extracted from the papers in the library questions composed test intent papers since measured.

\section{TEACHING RESOURCE MANAGEMENT AND RESOURCE SHARING}

The biggest advantage of online teaching than the rational allocation of resources and sharing of teaching. In order to give better play to the advantage of network teaching, teaching resources acquired systematic, scientific classification, storage, database of various teaching, teaching resource library components into a unified, comprehensive resource management system management. Teaching resource library, including the library of multimedia material, exam material library network courseware library literature database. All of these resources are indexed information. To query, browse and access.

Teaching resource sharing is the most important feature of online teaching. Teaching platform resource management system through the campus network to connect the various learning terminal, form a huge information network (see Figure 1). It should be noted that: the network of digitized voice laboratory is an important component of the teaching platform unit. Each language lab have left the network 
interface, and platform through the campus network connection to the language lab, under the control of the management system to achieve a variety of functions:

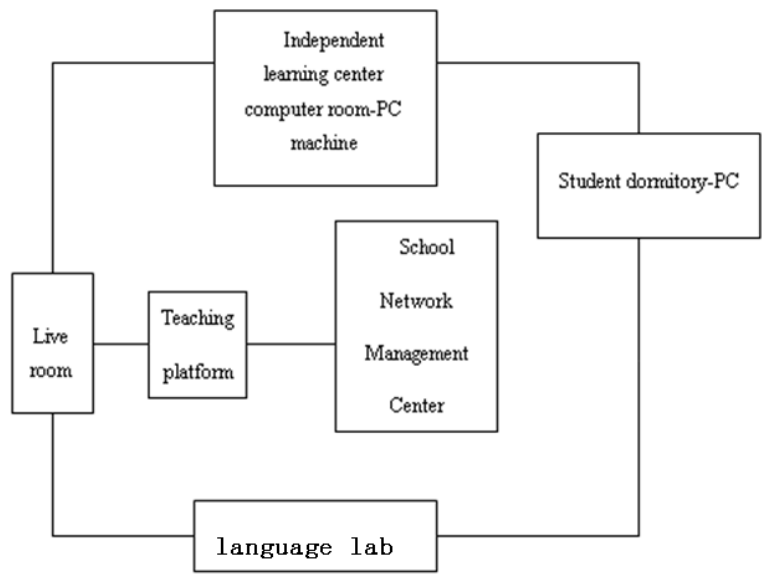

Figure 1. Digital language laboratory teaching network platform

1)Traditional language lab teaching function. Teachers can demonstrate teaching, two-way dialogue, group activities, electronic show of hands, and classroom exams.

2)Independent learning, self-test function. Students can demand either a shared resource server of hearing data or video materials local server and campus network to watch through the terminal display. Students can self-tune the resource on the server in the Open Test papers self-test after the examination is completed, the system automatically marking score.

3)Electronic preparation. The teachers can call the local repository, and campus network and external devices multimedia editing, made into a lesson plan or electronic papers, stored in a local repository or campus network repository.

4)Network management functions. Exams statistical functions, establish student files, student certification functions and fault detection functions.

\section{V.CONCLUSIONS AND OUTLOOK}

There is no doubt that the establishment of the network teaching platform of public foreign language teaching reform, the establishment of the new teaching mode to play an important role. However, to maintain the smooth, safe operation of the platform also need foreign language teachers, especially in the maintenance of a large number of professional and technical personnel. For example: regularly updated teaching materials, large-scale production of courseware, system security maintenance work. Some of the work but also understands the need to not only understands the foreign language teaching professional and technical people to be competent, but less complex talent. To solve this problem, some schools specifically established the the the Foreign Network Teaching Laboratory or Computer Assisted Language Teaching Laboratory, a team by the teaching staff and technical staff, the division of work to complete the maintenance work of the network platform. In fact, in the network teaching platform in the ordinary course of things, a lot of work is the maintenance of the platform. Than create a platform is more difficult, more challenging to maintain the normal operation of the teaching platform. Maintenance work is not in place, the operation and security of the network platform there will be a serious problem, which affects the effect of online teaching.

In short, college English the network teaching relying teaching platform to get the development of the teaching platform for network teaching tool support and technical support, but also reflects the style of teaching as a foreign language teachers to create and play opportunities intelligence. Although online teaching is still in the exploratory stage, but it pioneered open-autonomous learning and virtual teaching environment is changing the way teachers teach and students' learning habits. Internet course vivid, convenient, and sharing, interactive features to win universal praise for the students. It can be expected, as a modern means of education, online teaching has broad application prospects.

This paper is sponsored by the Hunan Province General Colleges and Universities Teaching Reform Project (No. 2012-401-482).

\section{REFERENCES}

[1] Gao Liming, modern educational technology [M] Beijing: China Central Radio and TV University Press, 1997

[2] Huji Yue, Zhang Guoying, Shen Lan-ping, English teaching model of curriculum development network research [J]. Waiyu Dianhua Jiaoxue, 2003,1, 12-15

[3] Holes Wen, Li Qinghua, Language Teaching and Computer Assisted Language Teaching [J] Waiyu Dianhua Jiaoxue, 2002, 2, 34-35

[4] Chuang Chih like, Wu Min, Huang Wei, the National Higher Education College English Teaching Online "new concept" pilot program [M] Shanghai Foreign Language Education Press, 2004,9

[5] Zhang, Modern Educational Technology and Foreign Language Teaching Mode [J] Waiyu Dianhua Jiaoxue,2002,1,48-50

[6] Yuan Pengfei, Intranet network construction and application development, [M] People's Posts and Telecommunications Press, 1999, 5

[7] Chambers, A. \& Bax, S. (2006) Making CALL work: Towards Normalization. System 34, 465- 479.

[8] Greeno, J., Collins, A. \& Resnick, L. (1996) Cognition and Learning. In R. Calfee \& D. Berliner (eds.), Handbook of Educational Psychology. New York: Macmillan.

[9] Jonassen, D. J. (1996) Handbook of Research for Educational Communication and Technology. New Jersey: Prentice Hall.

[10] Levy, M. and Stockwell, G. (2006) CALL Dimensions: Options and Issues in Computer-Assisted language Learning. Lawrence Erlbaum Associates, Inc.

[11] Morrison, G. R \& Lowther, D. L (2005) Integrating Computer Technology into Classroom. Pearson Education, Inc.. 